\title{
Erratum to: Home Informatics and Telematics
}

\author{
Andy Sloane ${ }^{1}$ and Felix van Rijn ${ }^{2}$ \\ 1 University of Wolverhampton, UK \\ 2 Educatieve Faculteit Amsterdam, The Netherlands
}

\section{Erratum to:}

\section{A. Sloane and F. van Rijn (Eds.) \\ Home Informatics and Telematics \\ DOI: $10.1007 / 978-0-387-35511-5$}

The book was inadvertently published with an incorrect name of the copyright holder. The name of the copyright holder for this book is: (c) IFIP International Federation for Information Processing. The book has been updated with the changes.

The updated original online version for this book can be found at DOI: $10.1007 / 978-0-387-35511-5$ 